\title{
ANALISIS KINERJA PHOTOVOLTAIK PADA STAND ALONE
}

\author{
Herman $\mathbf{H R}^{1)}$
}

\begin{abstract}
Solar Power Generation (SPG), or often called solar photovoltaic system, is one application of the use of solar energy as a source of electrical energy. This PLTS utilizes solar cells (photovoltaic) to generate electrical energy. The aimed of this research were to know the performance of PLTS installed power $150 \mathrm{Wp}$ stand alone and know how much power capacity can be supplied by PLTS. Solar Power Generation (Photovoltaics) most influenced by the intensity of sunlight depending on each region. Module with a capacity of $150 \mathrm{Wp}$ has been able to produce a mean power of 133.7 Watt / day. The expected output in this research was to create a good system and can contribute to student labs in laboratories and as an alternative source of energy in the Department of Mechanical Engineering and Maintenance, and beneficial for the development of electric power generation system in district of Fakfak. This research was also expected to produce Scientific Publications in local journals.
\end{abstract}

Keywords: Photovoltaic, Stand Alone, Modul WP 150.

\section{PENDAHULUAN}

Kebutuhan energi semakin besar seiring dengan pertambahan penduduk dan peningkatan aktifitas masyarakat. Pertambahan ini harus diimbangi dengan penambahan sumber-sumber energi baru. Sebagian besar energi yang kita gunakan sekarang ini berasal dari fosil yang tidak dapat diperbaharui dan akan habis jika di gunakan terus menerus sehingga manusia dituntut untuk mencari sumber-sumber energi lain yang sedapat mungkin sumber energi tersebut dapat diperbaharui atau terbarukan (Leksono, 2010). Energi baru dan yang terbarukan mempunyai peran yang sangat penting dalam memenuhi kebutuhan energi. Hal ini disebabkan penggunaan bahan bakar untuk pembangkit-pembangkit listrik konvensional dalam jangka waktu yang panjang akan menguras sumber minyak bumi, gas dan batu bara yang makin menipis dan juga dapat mengakibatkan pencemaran lingkungan. Salah satu upaya yang telah dikembangkan adalah Pembangkit Listrik Tenaga Surya (Bien dkk., 2008).

Pembangkit Listrik Tenaga Surya (PLTS) saat ini menjadi pembangkit listrik primadona, oleh karena energi primernya merupakan energi baru dan terbarukan sekaligus sebagai energi yang ramah terhadap lingkungan. Energi baru dan terbarukan saat ini terus digalakkan, selain untuk memenuhi kekurangan energi dari Pembangkit Listrik Negara (PLN), juga untuk menekan pemakaian sumber energi primer dan menekan tarif energi listrik yang cenderung naik mengikuti harga minyak global (Mansyur I, 2012).

Indonesia yang merupakan daerah tropis mempunyai potensi energi matahari sangat besar dengan insolasi harian rata-rata $4,5-4,8 \mathrm{kWh} / \mathrm{m}^{2}$ hari. Akan tetapi energi listrik yang dihasilkan sel surya sangat dipengaruhi oleh intensitas cahaya matahari yang diterima oleh sistem. Untuk kekontinuan ketersediaan listrik dan pemanfaatan energi listrik sel surya secara maksimal sangat diperlukan hibridasi dengan jala-jala listrik PLN (Bien dkk.,2008).

\footnotetext{
${ }^{1}$ Staf Jurusan Teknik Perawatan dan Perbaikan Mesin Politeknik Negeri Fakfak
} 
Pembangkit energi terbarukan masih kecil persentasinya. Secara kasat mata, Papua Barat khususnya di Kabupaten Fakfak sangat kekurangan daya listrik, maka dari pemerintah dalam hal ini Pihak PLN menyiapkan PLTS untuk memenuhi kebutuhan listrik untuk daerah Fakfak adalah 4,7 hingga 5 MW. Sementara pihak PLN baru memenuhi sekitar 2 MW jadi masih kekurangan daya sekitar 3 MW. Untuk itu, pihak PLN berusaha akan memasok tambahan daya listrik dengan menggunakan PLTS untuk kebutuhan masysrakat dan pemeritahan.

\section{METODE PENELITIAN}

\section{A. Prosedur/ Langkah Kerja}

Rancangan atau desain penelitian sangat diperlukan sebagai strategi untuk melaksanakan penelitian. Pada penelitian ini dikhususkan pada analisis kinerja Photovoltaik berdiri sendiri. Rancangan sistem dalam penelitian ini dengan menggunakan lbuah panel surya dengan kapasitas $150 \mathrm{Wp}$, Baterai Control Regulator (BCR) dengan kapasitas 10 A dan Baterai dengan kapasitas 40 Ah. Pada dasarnya setiap peralatan yang dibuat nantinya akan dirakit, setelah dirakit baru akan dilakukan pengujian peralatan. Tujuan pengujian ini untuk mengetahuai seberapa besar unjuk kinerja Photovoltaik dan optimalisi daya keluaran. Pengujian dilakukan setelah rangkaian selesai dipasang dengan benar.

Rancangan sistem Pvotovoltaik (stand alone) yang digunakan pada penelitian ini dapat dilihat pada gambar 1, di bawah ini:

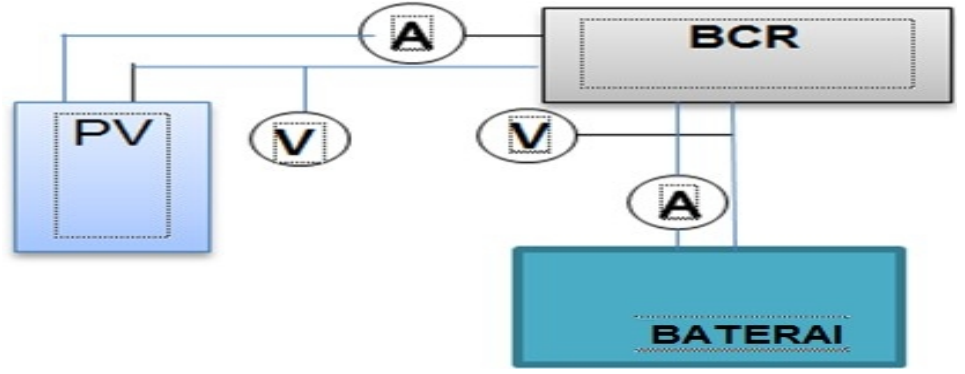

Gambar 1. Rangkaian sistem photovoltaic

\section{B. Prosedur/Langkah Pengujian}

Rancangan sistem terpasang 1 buah panel surya, dimana panel tersebut diuji dengan kapasitas solar sel $1 \times 150 \mathrm{Wp}$, output photovoltaik langsung berhubungan dengan battery control regulator (BCR), adapun fungsi dari alat ini sebagai pusat titik sambungan ke beban, dan baterai sebagai alat menyimpan energi listrik yang dihasilkan oleh Photovoltaik. Fungsi kedua adalah sebagai pengatur sistem agar penggunaan listrik aman dari bahaya perubahan level tegangan. BCR yang digunakan adalah type CS 990 dengan tegangan 12V-24V, keluaran dari BCR ini menjadi input inverter. Inverter ini berfungsi meruba tegangan DC ke tegangan $\mathrm{AC}$, sehingga bisa digunakan berbagi macam beban.

\section{Teknik Analisa Data}

Pengukuran sistem Photovoltaik hanya menerima energi dari sinar matahari ke baterai sampai dalam keadaan penuh melalui BCR. Dimana lama pengisian baterai sangat tergantung pada intensitas cahaya matahari yang diterima PV dan tergantung kapasitas panel untuk menghasilkan arus pengisian baterai. Baterai yang digunakan adalah merk GS berkapasitas 40 Ah dimana sebelumnya 
dikondisikan baterai kira-kira tegangan 11,86 Volt (dibuat overlow kondisi aki kisaran 40\%). Dengan mengunakan BCR 10A sebagai pengatur arus charging baterai. Berikut ini adalah rangkaian pengujian pengisian baterai (gambar 2).

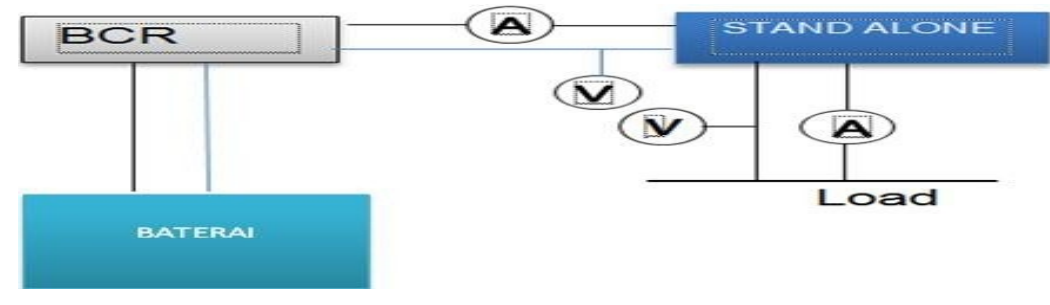

Gambar 2. Rangkaian pengujian sistem charger baterai

\section{HASIL DAN PEMBAHASAN}

\section{A. Hasil Analisis Sistem Photovoltaik}

Pengujian sistem Photovoltaik tanpa beban dari dilakukan dengan mengukur output (tegangan dan arus) dari modul yang dihasilkan. Adapun parameter yang digunakan adalah sumber cahaya matahari, antar selang waktu dari: jam $8.00 \mathrm{~s} / \mathrm{d} 16.00$ yang dilakukan selama 3 hari. Berdasarkan data hasil pengukuran didapatkan jumlah rata-rata yang dihasilkan pada hari ke 1 , yaitu sebesar tegangan17.24 V.dan arus rata 7,48 Ampere. Berikut ini data hasil grafik pengukuran tegangan dan arus pada hari ke-1.

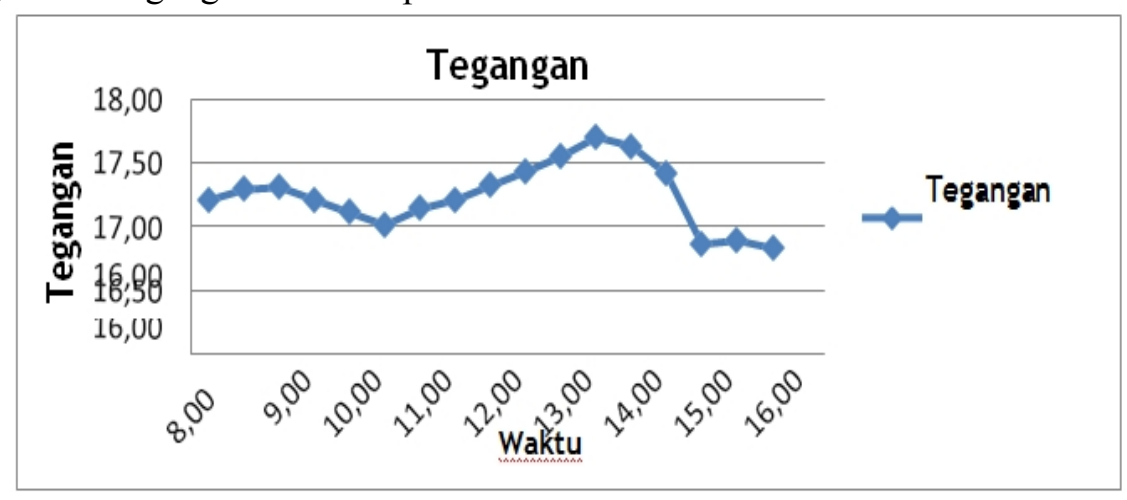

Gambar 3. Grafik Tegangan terhadap waktu hari ke 1

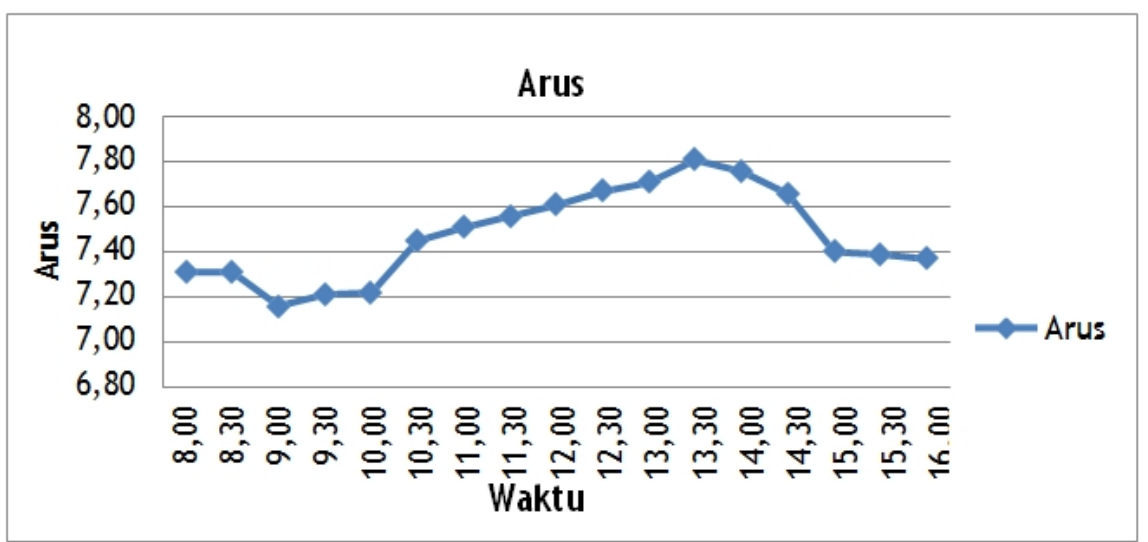

Gambar 4. Grafik Arus terhadap waktu hari ke 1 
Berdasarkan data hasil pengukuran didapatkan Lampiran A-2 Tabel 2 jumlah rata-rata yang dihasilkan pada hari ke-2, sebesar Tegangan $17,07 \mathrm{~V}$ dan Arus $=7,98 \mathrm{~A}$. berikut ini grafik hasil pengukuran tegangan dan arus pada hari ke2.

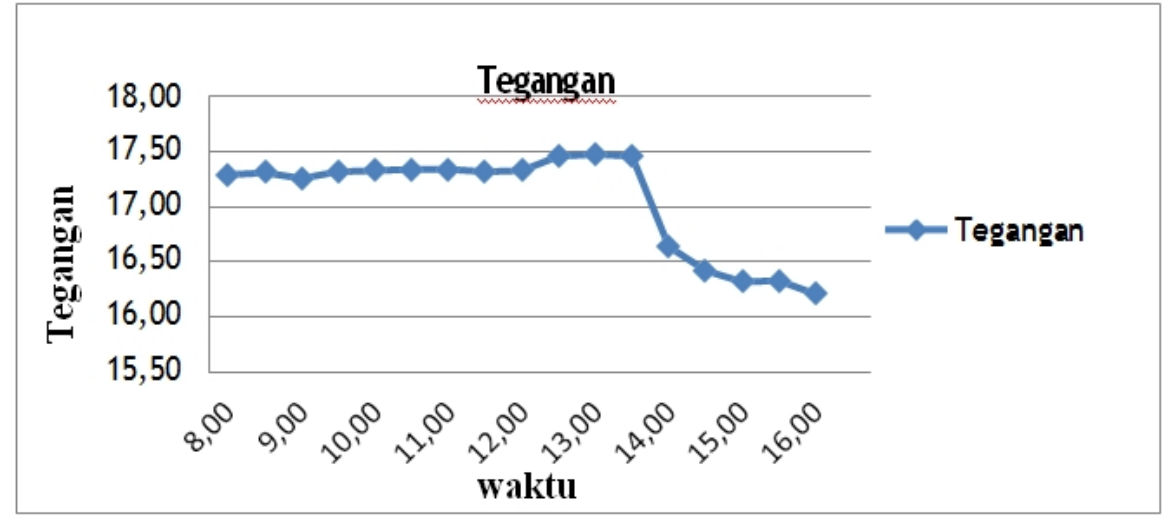

Gambar 5. Grafik Tegangan terhadap waktu pada hari ke 2

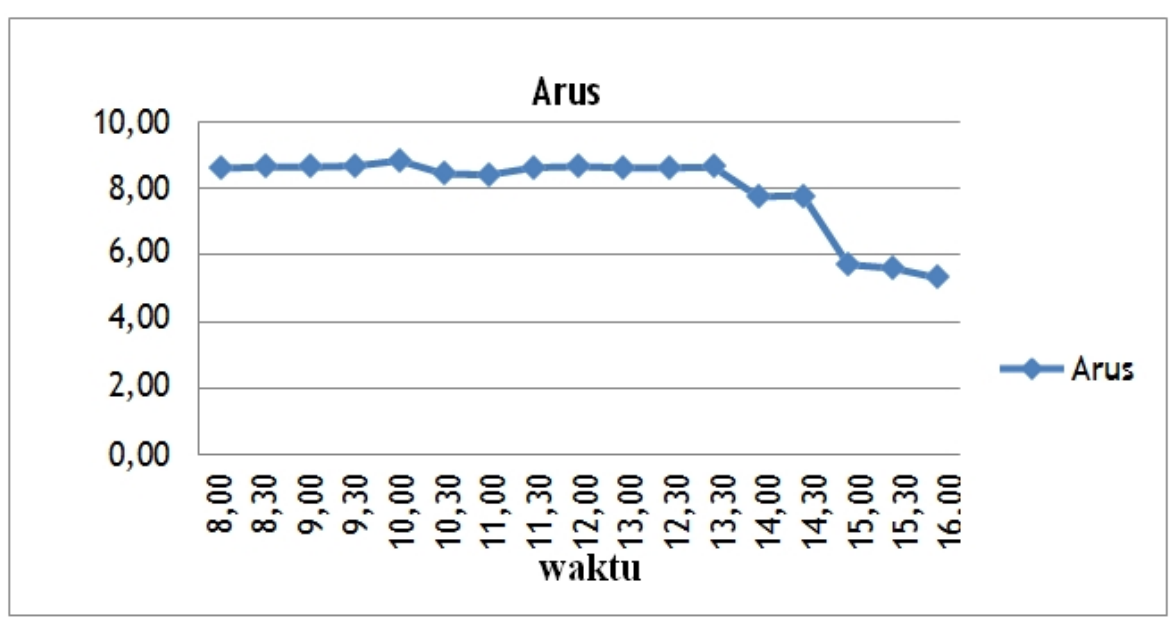

Gambar 6. Grafik Arus terhadap waktu pada hari ke 2

Data terakhir dari data hasil pengamatan didapatkan pada Lampiran A-3 Tabel 3, jumlah rata-rata yang dihasilkan pada hari ke-3 sebesar tegangan $=17,24$ $\mathrm{V}$ dan arus $=7.45 \mathrm{~A}$., berikut ini grafik hasil pengukuran tegangan.

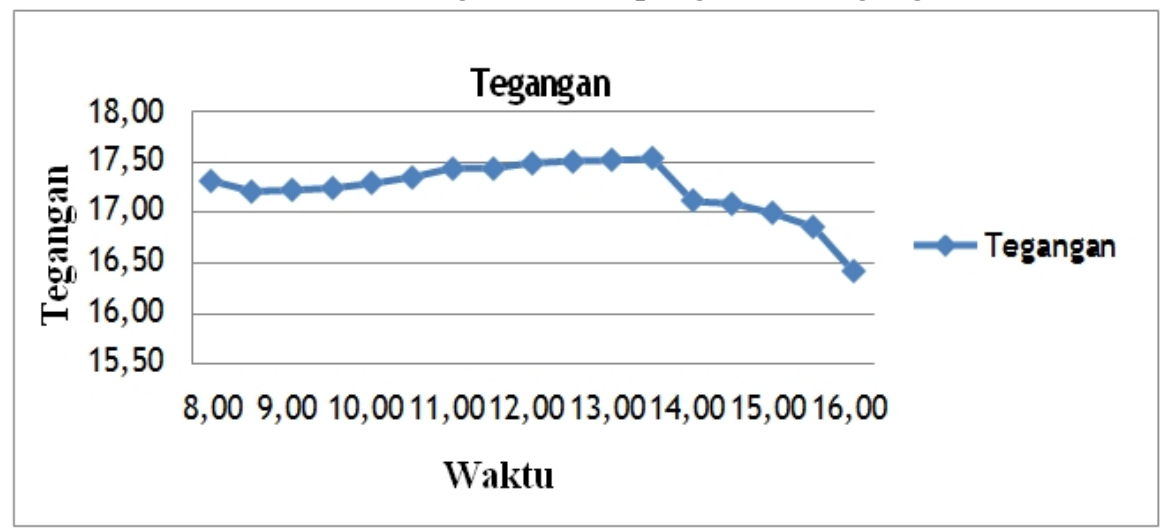

Gambar 7. Grafik tegangan terhadap waktu pada hari ke 3 


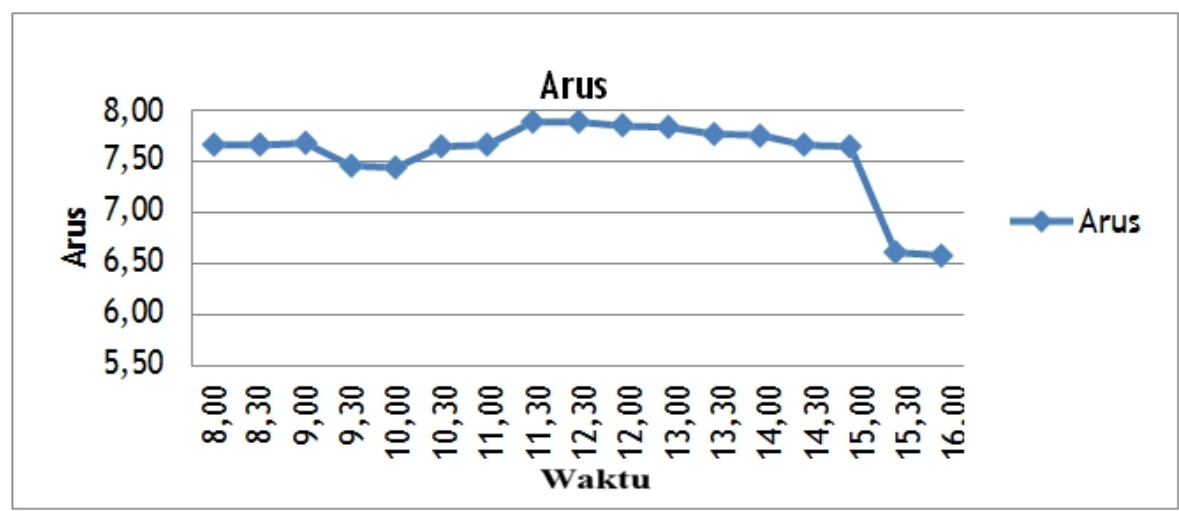

Gambar 8. Grafik arus terhadap waktu pada hari ke-3

\section{B. Pembahasan}

Produk yang dihasilkan dari analisis ini adalah berupa modul pembangkit dengan menggunakan photovoltaik, dimana modul pembangkit ini lebih efektif dan dapat digunakan untuk kebutuhan sehari-hari. Adapun nilai yang dihsilkan pada photovoltaik berupa arus dan tegangan, sehingga didapatkan kapasitas daya dari intentitas cahaya matahari. Berikut ini grafik hasil daya rata-rata yang dihasilkan photovoltaik selama 3 hari.

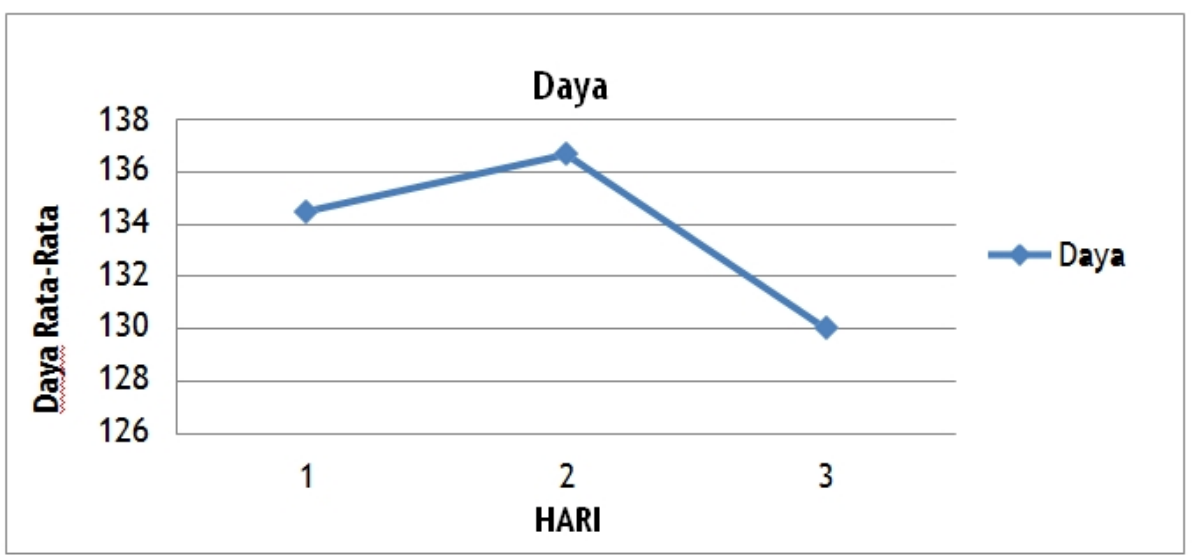

Gambar 9. Grafik Daya rata-rata selama 3 hari

Dari hasil analisis data, jumlah kapasitas daya rata-rata yaitu pada hari ke-1 sebesar 134,5 Watt, hari ke-2 sebesar 136,68 Watt dan hari ke-3 sebesar 130,024 Watt. Parameter diatas menunjukan bahwa nilai rata rata daya yang dihasilkan adalah 133,7 watt/hari. Penelitian ini dilakukan di Jurusan Teknik Pemeliharaan dan Perbaikan. Jalan Air Merah kampus Politeknik Negeri Fakfak.

\section{KESIMPULAN DAN SARAN}

\section{A. Kesimpulan}

Kesimpulan yang diperoleh dari hasil penelitian ini adalah sebagai berikut :

1. Kinerja Pembangkit Listrik Tenaga Surya (Photovoltaik) sangat dipengaruhi oleh intensitas cahaya matahari, sehingga luaran tegangan dan arus tidak maksimal/stabil.

2. Module dengan kapasitas $150 \mathrm{Wp}$ hanya mampu menghasilkan daya rata 133,7 Watt/hari. 


\section{B. Saran}

Dari kesimpulan peneliti maka saran yang dapat diberikan sehubungan dengan penelitian ini adalah:

1. Pada penelitian ini dapat dikembangkan untuk dijadikan tenaga hybrid dengan Turbin angin.

2. Dapat di interkoneksi dengan PLN (grid tie).

\section{DAFTAR PUSTAKA}

Arikunto, Suharsimi. (2009). Prosedur Penelitian Suatu Pendekatan Praktik. Jakarta: Rineka Cipta.

Badan Pusat Statistik Republik Indonesia . ( 2010 ).Penduduk Indonesia Menurut Desa Hasil Sensus Penduduk 2010. Jakarta : Badan Pusat Statistik Republik Indonesia.

Biem Ek Liem dan kawan-kawan ( 2012) Perancangan Sistem Hibrid Pembangkit Listrik Tenaga Surya Dengan Jala-Jala Listrik PLN Untuk Rumah Perkotaan. Dosen-Dosen Jurusan Tehnik Elektro Universitas Trisakti ISSN 1412-0372.

Bell Telephone (1954) Sel surya silicon berbasis p-n junctiondenganefisiensi 6\%.

Daryanto.(1987). Pengetahuan Teknik Listrik. Jakarta: Bina Aksara.

Departemen Pendidikan Nasional. 2005. Kamus Besar Bahasa Indonesia. Balai Pustaka, Jakarta.

Kadir, A. 1995. Energi:Sumber daya, inovasi, tenaga listrik, potensi ekonomi. Cet 1. Edisi Kedua/Revisi. Universitas Indonesia Press, Jakarta.

Michael, Rudolf, (1995). Pengisi baterai dan Akumulator. Solo: Aneka. 